\title{
Problematyka ochrony dziedzictwa kulturowego w działalności międzynarodowych trybunałów karnych
}

\section{Wprowadzenie}

Emer de Vattel - XVII-wieczny klasyk prawa międzynarodowego - w swoim dziele zatytułowanym Prawo narodów lub zasady prawa naturalnego pisał: „z jakiejkolwiek przyczyny kraj został zniszczony, to budynki, które nie tworzą potęgi wroga, takie jak świątynie, nagrobki, gmachy publiczne, wszelkie dzieła odznaczające się swym pięknem, powinny być oszczędzone"1. Ponad dwa i pół wieku później społeczność międzynarodowa zgodnie powtarza, że dobrom kultury należy się ochrona i w interesie ogólu jest zachowanie ich w jak najlepszym stanie. Przekonanie to znajduje potwierdzenie w licznych aktach prawnych uchwalonych zarówno na poziomie krajowym, jak i regionalnym oraz międzynarodowym. Dlaczego więc, mimo wydawać by się mogło kompleksowej regulacji zagadnienia ochrony dóbr kultury, nieustannie mamy do czynienia z niszczeniem kulturowego dorobku na masową wręcz skalę?

Bieżące wydarzenia dobitnie dowodzą nieskuteczności prawnych regulacji. Ich nieefektywność obnaża w szczególności kulturalna tragedia, z którą mierzą się dziś Syria i Irak. Casus ten nie jest bynajmniej odosobniony. Historia zna liczne przypadki, w których prawo nie zdołało zapobiec „kulturalnej katastrofie”. Strat poniesionych w trakcie dwóch wojen światowych nie powstrzymały konwencje haskie, których celem było zapobieżenie niszczycielskim skutkom działań zbrojnych². Schyłek XX oraz początek XXI wieku również nie były dla dóbr kultury łaskawe. Ogrom zniszczeń towarzyszących konfliktowi jugosłowiańskiemu, destrukcja posągów Buddy w Bamianie (Afganistan),

1 E. Vattel, Prawo narodów, czyli zasady prawa naturalnego zastosowane do postępowania i spraw narodów i monarchóww, t. 2, Warszawa 1958, s. 170.

2 Problematyce ochrony dóbr kultury poświęcona była w szczególności Konwencja dotycząca praw i zwyczajów wojny lądowej. Zobowiązywała ona do oszczędzenia obiektów przedstawiających wartość kulturalną w przypadku oblężenia i bombardowania (art. 27), wprowadzająca zakaz zajmowania, niszczenia i profanacji obiektów tego rodzaju (art. 56) oraz zakaz rabunku (art. 47). Tekst Konwencji: Dz.U. 1927 nr 21 poz. 161. 
agresja islamskich fundamentalistów w Timbuktu (Mali) czy masowe niszczenie skarbów kultury w Iraku i Syrii dowodzą, że nawet późniejsze, bardziej szczegółowe regulacje nie gwarantują dziedzictwu kulturowemu bezpieczeństwa ${ }^{3}$. Nieskuteczność instrumentarium prawnego dostrzega sama Dyrektor Generalna UNESCO - Irina Bokova, według której w dobie rozwoju świata prawo nie jest tak szybkie jak rakiety ${ }^{4}$. Oznacza to, że międzynarodowa wspólnota stoi dziś przed nie lada wyzwaniem. By mu sprostać, konieczne jest umieszczenie problematyki ochrony dziedzictwa kulturowego w szerszym kontekście bezpieczeństwa międzynarodowego. Wydaje się, że realizacja tego postulatu jest możliwa dzięki położeniu akcentu na rolę międzynarodowego prawa karnego i na egzekwowaną w jego ramach odpowiedzialność indywidualnych jednostek ${ }^{5}$. Urzeczy-

3 Do najważniejszych uniwersalnych aktów prawnych z zakresu ochrony dóbr kultury należy zaliczyć Konwencję o ochronie dóbr kulturalnych w razie konfliktu zbrojnego z 1954 r. (Dz.U. $1957 \mathrm{nr} 46$ poz. 212), Konwencję dotyczącą środków zmierzających do zakazu i zapobiegania nielegalnemu przywozowi, wywozowi i przenoszeniu własności dóbr kultury z 1970 r. (Dz.U. 1974 nr 20 poz. 160) oraz Konwencję w sprawie ochrony światowego dziedzictwa kulturalnego i naturalnego z 1972 r. (Dz.U.1976 nr 32 poz. 190).

4 I. Bokova, Culture in the Cross Hairs, „The New York Times” z 2.12.2012 r., http://www.nytimes. com/2012/12/03/opinion/global/cultural-sites-must-be-protected.html [dostęp: 4.02.2016].

5 Potrzebę karania czynów przestępczych skierowanych przeciwko dobrom kultury dostrzeżono już znacznie wcześniej. W projekcie deklaracji międzynarodowej dotyczącej praw i zwyczajów wojny (powszechnie nazywanym deklaracją brukselską) z 1874 r. czytamy: „Wszelkie zajęcie, zniszczenie lub rozmyślne zbezczeszczenie [...] zabytków historycznych, dzieł sztuki i nauki powinno być ścigane przez właściwe władze" (tekst deklaracji: S. Nahlik, Międzynarodowa ochrona dóbr kulturalnych. Zbiór tekstórw, Warszawa 1962, s. 109). Podobnie na mocy art. 56 konwencji haskiej dotyczącej praw i zwyczajów wojny lądowej: „Wszelkie zajęcie, zniszczenie lub rozmyślna profanacja [...] pomników historycznych, dzieł sztuki i nauki, są zabronione i winny być karane". Konwencja haska o ochronie dóbr kulturalnych w razie konfliktu zbrojnego z 1954 r. idzie jeszcze dalej. Można zaryzykować stwierdzenie, że jej art. 28 wprowadza nawet koncepcję jurysdykcji uniwersalnej. Stanowi on bowiem, że „Wysokie Umawiające się Strony zobowiązują się powziąć w ramach swoich systemów prawa karnego wszelkie konieczne środki, ażeby osoby, które dopuściły się naruszenia niniejszej Konwencji lub nakazały jej naruszenie, były bez względu na swoje obywatelstwo ścigane i dosięgnięte sankcjami bądź karnymi, bądź dyscyplinarnymi”. Możliwość nałożenia sankcji na sprawców przestępstw przeciwko dobrom kultury wynika również z I Protokołu dodatkowego do konwencji genewskich z 1949 r. Na mocy art. 85 ust. 4 pkt d) „kierowanie ataków przeciwko pomnikom historycznym, dziełom sztuki lub miejscom kultu religijnego wyraźnie rozpoznanym, które stanowią dziedzictwo kulturalne lub duchowe narodów i którym przyznana została szczególna ochrona na mocy odrębnego porozumienia, na przykład w ramach uprawnionej organizacji międzynarodowej, powodujących przez to ich zniszczenie na dużą skalę, gdy brak dowodu, że strona przeciwna naruszyła artykuł 53 punkt (b), i gdy te pomniki historyczne, dzieła sztuki i miejsca kultu religijnego nie są położone w bezpośredniej bliskości celów wojskowych, stanowi zbrodnię wojenną, za którą sprawca, niezależnie od jego obywatelstwa i miejsca popełnienia zbrodni, będzie ponosił odpowiedzialność" (tekst protokołu: Dz.U. 1992 nr 41 poz. 175, załącznik). Jeszcze bardziej precyzyjne są postanowienia art. 15 Drugiego Protokołu do Konwencji o ochronie dóbr kulturalnych w razie konfliktu zbrojnego. Określono w nim bowiem, jakie konkretnie czyny stanowią poważne naruszenie Protokołu i tym samym mogą stanowić podstawę odpowiedzialności karnej. Zgodnie 
wistnienie idei penalizacji szkód wyrządzonych w dorobku kulturowym narodów możliwe jest współcześnie dzięki istnieniu Międzynarodowego Trybunału Karnego (MTK), na forum którego najbardziej barbarzyńskie zbrodnie są nie tylko moralnie potępiane, ale także konsekwentnie ścigane, a ich sprawcy sprawiedliwie karani ${ }^{6}$.

\section{Penalizacja bezprawnych działań wymierzonych w dziedzictwo kulturowe}

\section{Postępowanie przed Międzynarodowym Trybunałem Wojskowym}

Państwa przekonane o ponadnarodowej wartości dóbr kultury i kolektywnym interesie $\mathrm{w}$ ich zachowaniu już dawniej podejmowały wysiłki zmierzające do penalizacji czynów przestępczych wymierzonych w dziedzictwo kulturowe. Pierwszą w historii próbą egzekwowania międzynarodowego prawa humanitarnego dotyczącego ochrony dóbr kultury był proces przed Międzynarodowym Trybunałem Wojskowym w Norymberdze (MTW). Podczas II wojny światowej całkowicie ignorowano nawet najbardziej podstawowe normy prawa międzynarodowego, w tym te nakazujące uprzywilejowane traktowanie dóbr kultury. Skala popełnionych wówczas zbrodni nie pozwalała wątpić, że za każdy akt barbarzyństwa zbrodniarze wojenni muszą zostać pociągnięci do odpowiedzialności. Jurysdykcja MTW w zakresie czynów przestępczych skierowanych przeciwko dobrom kultury (tj. zbrodni wojennych) wynikała z art. 6 lit. b Karty Międzynarodowego Trybunału Wojskowego, zgodnie z którym: „Pogwałcenia takie będą obejmowały, nie ograniczając się jednak do nich: [...] grabież mienia publicznego lub prywatnego, zbyteczne niszczenie miast, miasteczek lub wsi oraz pustoszenie kraju nie usprawiedliwione koniecznością wojskową" '. Zarzuty na podstawie wspomnianego artykułu usły-

ze wskazanym przepisem: „1. Każda osoba popełnia przestępstwo w rozumieniu niniejszego protokołu, jeżeli celowo i z naruszeniem konwencji lub niniejszego protokołu dopuszcza się któregokolwiek z następujących czynów: a) czyni celem ataku dobro kulturalne objęte ochroną wzmocnioną; b) wykorzystuje dobro kulturalne objęte ochroną wzmocnioną lub jego najbliższe otoczenie do wsparcia działań wojskowych; c) powoduje rozległe zniszczenia lub zawłaszcza dobro kulturalne objęte ochroną na mocy konwencji lub niniejszego protokołu; d) czyni dobro kulturalne objęte ochroną na mocy konwencji i niniejszego protokołu celem ataku; e) dokonuje kradzieży, rabunku lub przywłaszczenia bądź popełnia akty wandalizmu skierowane przeciwko dobrom kulturalnym objętym ochroną na mocy konwencji. 2. Każda ze Stron podejmie takie kroki, jakie mogą być niezbędne, aby w ramach prawa krajowego zostały uznane za przestępstwo czyny uznane za przestępstwo na mocy niniejszego artykułu i aby przestępstwa takie podlegały odpowiednim karom. Czyniąc to, każda ze Stron będzie postępować zgodnie z ogólnymi zasadami prawa i prawa międzynarodowego, w tym z normami rozszerzającymi indywidualną odpowiedzialność karną na osoby inne niż te, które bezpośrednio popełniły dany czyn" (tekst protokołu: Dz.U.2012 poz. 248).

6 J. Izydorczyk, P. Wiliński, Międzynarodowy Trybunat Karny: porwstanie, organizacja, jurysdykcja, Akty prawne, Kraków 2004, s. 18-19.

7 Tekst Karty Międzynarodowego Trybunału Wojskowego: Dz.U.1947 nr 63 poz. 367. 
szeli m.in. Hermann Goering - sądzony za liczne akty grabieżcze, właściciel prywatnej kolekcji sztuki oraz Alfred Rosenberg - szef planowo przeprowadzonej akcji grabieżczej, kierownik sztabu operacyjnego Einsatzstab Rosenberg, zajmującego się rabunkiem dzieł sztuki w okupowanych krajach Europy ${ }^{8}$. Z oczywistych względów figurujące w rejestrze win zarzuty dotyczące burzenia miast i grabieży dzieł sztuki stanowiły jedynie fragment obszernych aktów oskarżenia. Należy jednak podkreślić, że choć czynom tym poświęcono w trakcie procesu norymberskiego niewiele miejsca w porównaniu z pozostałymi typami zbrodni, to wyrok dowiódł, że winni „zbrodni przeciwko kulturze” zostaną ukarani.

\section{Postępowanie przed Międzynarodowym Trybunałem Karnym ds. byłej Jugosławii}

Niemal pół wieku później kwestię naruszeń prawa humanitarnego podczas konfliktu lat 90. na Bałkanach badał Międzynarodowy Trybunał Karny ds. byłej Jugosławii (MTKJ). W celu osądzenia osób odpowiedzialnych za ogrom towarzyszących konfliktowi zniszczeń dóbr kultury powoływano się na art. 2 lit. d, zgodnie z którym: „Międzynarodowy Trybunał ma prawo do sądzenia osób, które popełniły lub wydały rozkaz popełnienia ciężkich naruszeń konwencji genewskich z 12 sierpnia 1949 r., a mianowicie następujących czynów skierowanych przeciwko osobom lub dobrom chronionym na podstawie przepisów konwencji genewskich: [...] (d) niszczenie i przywłaszczanie majątku nie usprawiedliwione koniecznością wojskową i dokonywane na wielką skalę w sposób niedozwolony i samowolny”, oraz art. 3 lit. d Statutu MTKJ w brzmieniu: „Międzynarodowy Trybunał ma prawo do sądzenia osób, które naruszyły prawa lub zwyczaje wojenne. Takie naruszenia będą obejmowały następujące naruszenia, przy czym nie będą do nich ograniczone: [...] (d) zajmowanie, niszczenie lub umyślne uszkadzanie instytucji kościelnych, dobroczynnych i wychowawczych, artystycznych i naukowych, pomników historycznych i dzieł sztuki oraz nauki" ${ }^{9}$. Na gruncie Statutu czyny te stanowią jedno z naruszeń należących do szerszej kategorii zbrodni wojennej. Za taką zbrodnię uznano m.in. akt destrukcji, który w największym stopniu przykuł wówczas uwagę opinii publicznej. Mowa oczywiście o tragicznym w skutkach zbombardowaniu Starego Miasta w Dubrowniku, wpisanego na Listę dziedzictwa światowego UNESCO ${ }^{10}$. Realizując

8 W sentencji wyroku MTW czytamy, że w okresie od marca 1941 r. do lipca 1944 r. do Rzeszy przewieziono 29 załadunków, w skład których wchodziło 137 wagonów towarowych przewożących 4174 dzieła sztuki. Cf. Trial of the Major War Criminals Before the International Military Tribunal, Nuremberg, 14 November 1945 - 1 October 1946, s. 241-242.

9 Tekst Statutu Międzynarodowego Trybunału do Sądzenia Osób Odpowiedzialnych za Poważne Naruszenia Międzynarodowego Prawa Humanitarnego Popełnione na Terytorium byłej Jugosławii od 1991 r. dostępny na stronie internetowej w tłum. E. Mikos-Skuzy: http://www. pck.org.pl/pliki/mph/1993_Haga_-_Statut_MTKJ.pdf [dostęp: 18.02.2016].

10 Dubrownik został oblężony przez wojska federalne już pod koniec 1991 r., a stan ten utrzymywał się przez 392 dni. W tym okresie miasto było wielokrotnie bombardowane zarówno od strony morza, jak i lądu. Serie bombardowań uszkodziły $68 \%$ zabudowy starego miasta - zniszczono większość dachów, ale również kościoły, klasztory i mury miejskie. Okazało się, 
swoje statutowe uprawnienia, 31 stycznia 2005 r. Międzynarodowy Trybunał Karny ds. byłej Jugosławii skazał na karę więzienia generała ówczesnej Jugosłowiańskiej Armii Ludowej - Pavle Strugara. Analiza postawionych mu zarzutów (sformułowanych na ponad 30 stronach) pozwala wnioskować, że dopuścił się on dwojakiego rodzaju naruszeń międzynarodowego prawa humanitarnego: ataków na ludność cywilną oraz destrukcji obiektów cywilnych i dóbr kultury. W postępowaniu przed Izbą Apelacyjną uwzględniono ponadto dwa inne zarzuty wniesione przez prokuratora. Były to kolejno: przestępstwo nieuzasadnionego koniecznością wojskową zniszczenia dóbr kultury oraz przestępstwo bezprawnego ataku na obiekty cywilne ${ }^{11}$. W tej samej sprawie oskarżony i skazany na karę więzienia został ponadto podwładny generała - admirał Miodrag Jokić. W obu przypadkach dokonując oceny ciężaru gatunkowego przestępstwa, Trybunał zwrócił uwagę na uprzywilejowany status Starego Miasta w Dubrowniku, wpisanego na Listę dziedzictwa światowego. Okoliczność ta została uwzględniona, gdyż w ocenie Trybunału zniszczenie dobra o wyjątkowej powszechnej wartości stanowiło uszczerbek nie tylko dla spuścizny regionu, lecz także dla dziedzictwa całej ludzkości. Obaj oskarżeni zostali skazani na karę więzienia - Strugar w wymiarze 7,5 roku, zaś Jokić 7 lat ${ }^{12}$.

\section{Postępowanie przed Międzynarodowym Trybunałem Karnym}

Z dniem, w którym wszedł w życie Statut MTK, tj. 1 lipca 2002 r., doszło do ukonstytuowania zasady uniwersalnej odpowiedzialności karnej za popełnione zbrodnie. Do tej pory, za sprawą specjalnych trybunałów karnych oraz sądów ad hoc, wymierzanie sprawiedliwości było ograniczone personalnie bądź terytorialnie. Ustanowienie stałego trybunału miało zagwarantować realizację norm prawnomiędzynarodowych, nie tylko

że na fasady budynków oraz ulice miasta spadło ogółem ponad 300 pocisków artyleryjskich. Zabytkowe mury miejskie zostały uszkodzone przez kolejne 111 pocisków. Zastraszające rozmiary przybrały efekty pożarów wywołanych ostrzałem. Aż 9 pałaców w mieście strawił ogień, kilka innych zostało poważnie uszkodzonych. Należały do nich m.in. Pałac Sponza i Pałac Rektorów. Ogółem w historycznym centrum miasta zniszczeniu uległy 382 budynki mieszkalne, 19 budowli o charakterze religijnym oraz 10 instytucji publicznych. Łącznie z uszkodzonymi dachami bilans strat wynosil 594 zniszczone obiekty na powierzchni ponad $190 \mathrm{~m} \mathrm{kw}$. Cf. D. Ratkowić, Chorwacja - skutki wojny, „Cenne, bezcenne/utracone” 1997, nr 2; oraz dane ze strony internetowej Instytutu Renowacji Dubrownika: http://www.zod.hr/eng/novost. php?id=50 [dostęp: 2.04.2015], a także strony poświęconej turystycznym walorom Chorwacji: http://www.cro.pl/dubr2.php?param=1 [dostęp: 2.04.2015].

11 H. Schreiber, Konwencja o ochronie dóbr kulturalnych w razie konfiktu zbrojnego wraz z Regulaminem wykonawczym do tej Konwencji oraz Protokót o ochronie dóbr kulturalnych w razie konfliktu zbrojnego podpisane w Hadze dnia 14 maja 1954 r., [w:] Konwencje UNESCO w dziedzinie kultury. Komentarz, red. K. Zalasińska, Warszawa 2014, s. 90-91.

12 Cf. wyroki Prokurator v. Pavle Strugar, sprawa nr IT-01-42-T, orzeczenie Izby Orzekającej z dnia 31 stycznia 2005 r.; Prokurator v. Pavle Strugar, sprawa nr IT-01-42-A, orzeczenie Izby Apelacyjnej z dnia 17 lipca 2008 r.; Prokurator v. Miodrag Jokić, sprawa nr IT-01-42/1-S, orzeczenie Izby Orzekającej z dnia 18 marca 2004 r. 
na szczeblu lokalnym, ale także globalnym. W skali globalnej należy postrzegać także zagrożenia dla kulturowego dorobku. Jak bowiem pokazują kolejne przykłady, dobra kultury są narażone na niebezpieczeństwo w różnych zakątkach świata. Niezależnie od szerokości geograficznej - czy to w Europie, Afryce, czy w Azji - popełniane są zbrodnie wojenne polegające na ich celowym niszczeniu. MTK powinien stanowić skuteczną odpowiedź na tego typu naruszenia.

\section{Timbuktu - studium przypadku}

Założenie miasta Timbuktu (Mali) datuje się na XI wiek. Jego fundatorami byli Tuaregowie Magharen - koczowniczy lud berberski. Początkowo była to jedna $z$ wielu osad powstałych w dolinie Nigru, jednak ze względu na szczególnie dogodne położenie, na skrzyżowaniu szklaków handlowych, Timbuktu przekształciło się wkrótce w wysoko rozwinięty ośrodek miejski. Mimo nieustających przemian politycznych, zmian rządów, podbojów i prześladowań, naprzemiennego wzrostu i upadku swej potęgi, aż do XVII wieku stopniowo rosło w siłę. Co ciekawe, nie tylko strategiczne położenie geograficzne i pomyślność gospodarcza uczyniły z Timbuktu jedno z ważniejszych miast w Afryce Zachodniej. Poza pierwszorzędną pozycją w gospodarce, miasto mogło poszczycić się także niezwykle bogatą kulturą. Była ona zasługą społecznego i etnicznego zróżnicowania zamieszkującej je ludności. Kulturotwórczej koegzystencji różnych grup językowych, rasowych i religijnych sprzyjała panująca w mieście atmosfera wzajemnej tolerancji i akceptacji. Na tle owej różnorodności na pierwszy plan wybijała się kultura muzułmańska rozwijana w Timbuktu przez środowisko ulemów. Ze względu na licznie występujące niegdyś w mieście koraniczne placówki oświatowe (ok. 180), w tym Uniwersytet Sankore, Timbuktu uważane było nawet za najważniejszy ośrodek islamu w Afryce Zachodniej ${ }^{13}$. Przez wieki formował się więc bogaty dorobek cywilizacyjny miasta, którego tajemniczy charakter od dawna fascynował mieszkańców Europy. Najlepszym wyrazem powszechnego uznania dla wspaniałej przeszłości i kulturowego bogactwa Timbuktu było wpisanie go w 1988 r. na Listę światowego dziedzictwa UNESCO. Jak się jednak okazało, wpis nie zdołał zapobiec katastrofie i nie zapewnił zabytkom bezpieczeństwa. Zagrożenie dla skarbów kultury przyszło wraz ze zmianami politycznymi. Niemal ćwierć wieku później, 21 marca 2012 r., grupa rebeliantów dokonała w Mali zamachu stanu. Walki na północy kraju doprowadziły do destabilizacji państwa, a wkrótce do obalenia ówczesnego prezydenta Amadou Toumani Touré. Sytuację tę szybko wykorzystali zrzeszeni w ramach Narodowego Ruchu Wyzwolenia Azawadu Tuaregowie, którzy już 6 kwietnia 2012 r. ogłosili niepodległość Azawadu - regionu w północnej części Mali14. „Niepodległościowców” wsparło ugrupowanie Ansar ad-Din (dosłownie:

13 Szerzej: M. Tymowski, Dzieje Timbuktu, Wrocław - Warszawa - Kraków - Gdańsk 1979.

14 Tuaregs claim 'independence' from Mali, http://www.aljazeera.com/news/africa/2012/04/2012 4644412359539.html [dostęp: 10.02.2016]. 
Obrońcy Wiary) - powiązany z Al Kaidą islamski oddział bojowników. Początkowo jako sojusznicy razem walczyli oni przeciwko malijskiemu wojsku, wkrótce jednak, wbrew życzeniom Tuaregów, islamscy bojownicy zaczęli samowolnie narzucać surowe prawo szariatu na obszarze całego Azawadu. Z końcem czerwca 2012 r. pod okupacją tych religijnych fundamentalistów znalazły się największe miasta regionu, w tym antyczne Timbuktu. Od tego momentu ortodoksyjni wyznawcy islamu dokonywali systematycznej destrukcji zabytków znajdujących się w mieście. Reakcja całej wspólnoty międzynarodowej, jak i organizacji stojącej na straży kultury i dziedzictwa kulturowego była natychmiastowa. Już 28 czerwca 2012 r. UNESCO dokonało wpisu Timbuktu na Listę dziedzictwa światowego w niebezpieczeństwie ${ }^{15}$. Po raz kolejny okazało się jednak, że choć zamysł i chęci były godne uznania, to akt ten nie miał żadnego praktycznego znaczenia. Wręcz przeciwnie, w wyniku eskalacji agresji sytuacja dóbr kultury w regionie uległa znacznemu pogorszeniu. Wbrew oczekiwaniom wszelkie apele kierowane do islamskich radykałów nie tylko nie powstrzymały, ale wręcz wzmogły ich niszczycielską działalność. 7 lipca rzecznik ugrupowania Ansar ad-Din - Sanda Ould Boumama, określił wszystkie znajdujące się mieście budynki terminem haram, co w islamie znaczy „zakazany”. Grzmiał: „Wszystkie świątynie zostaną zniszczone. Wszyscy jesteśmy muzułmanami. Czym natomiast jest UNESCO? Kulturowe dziedzictwo nie istnieje. Niewierni nie mają prawa mieszać się w nasze sprawy”16. W trakcie trwającej ponad pół roku okupacji islamscy radykałowie spełnili swe groźby. Timbuktu, znane jako „miasto 333 świętych", obfitujące dotychczas w grobowce i mauzolea sufickich świętych, stało się areną bestialskich i bezmyślnych ataków. Ich ofiarą padły przede wszystkim najcenniejsze mauzolea i meczety, których wznoszenie było przecież zgodne ze znanym sufizmowi kultem świętych. Z kolei przez ortodoksyjnych islamistów wszelkie przykłady sztuki figuralnej postrzegane były jako bluźnierstwo wobec Allaha. Konflikt pomiędzy islamem postępowym a wstecznym fundamentalizmem skończył się dla bezcennych dóbr kultury tragicznie. „Talibowie Sahelu” zniszczyli co najmniej dziewięć z szesnastu mauzoleów oraz dwa $\mathrm{z}$ trzech wielkich meczetów ${ }^{17}$. Wszystkie te obiekty wpisane były uprzednio na Listę światowego dziedzictwa UNESCO. Widmo zniszczenia zawisło także nad przechowywanymi w mieście manuskryptami, których liczba szacowana była na ponad 700 tysięcy. Szczęśliwie dzięki szybkiej interwencji opiekunów zbiorów najważniejsze z nich

15 http://whc.unesco.org/en/news/893/ [dostęp: 16.02.2016].

16 J. Petrovic, What next for endangered cultural treasures? The Timbuktu crisis and the responsibility to protect, „New Zealand Journal of Public and International Law” 2013, nr 11, s. 388.

17 Zniszczenia objęły mauzolea sufickich świętych znane pod nazwami: Cheikh Sidi Mahmoud, Alpha Moya, Mohamed Tamba-Tamba, Cheikh Sidi Ahmed Raggadi, Cheikh Sidi Elmicki, Abul Quassim al Tawaty, Cheikh Sidi Elmoctar, Sidi Mohamed Boukkou oraz Mohamed Sangare le Peul. Częściowej destrukcji uległy ponadto meczety - Dżingereber oraz Sidi Yahia. V. State of Conservation (SOC): Timbuktu, 2013, http://whc.unesco.org/en/soc/1865 [dostęp: 22.02.2016]. 
udało się uratować ${ }^{18}$. Stabilizacja sytuacji w regionie, a co za tym idzie - przywrócenie zagrożonym dobrom kultury względnego bezpieczeństwa było zasługą malijskich i francuskich interwencji wspartych przez siły krajów stowarzyszonych w ECOWAS ${ }^{19}$. $\mathrm{Na}$ tym tle należy zauważyć, że kondycja miejscowych dóbr kultury, tj. stan ich zagrożenia lub względnego bezpieczeństwa, była jedynie wypadkową działań podejmowanych w celu stabilizacji sytuacji politycznej. Nie podjęto natomiast żadnej akcji bezpośrednio ukierunkowanej na ochronę kulturowego dziedzictwa. Jego bezpieczeństwo potraktowano więc jako problem wtórny wobec innych, jak sądzono ważniejszych kwestii ${ }^{20}$. Reakcja Rady Bezpieczeństwa ONZ ograniczała się jedynie do wydania rezolucji w sprawie pokoju i bezpieczeństwa w Afryce, w której zdecydowanie potępiono profanację, uszkadzanie i niszczenie miejsc kultu o znaczeniu historycznym i kulturowym, w szczególności obiektów wpisanych na Listę światowego dziedzictwa UNESCO, w tym tych znajdujących się w Tibuktu². Można mieć uzasadnione wątpliwości, czy tego typu sankcje psychologiczne są w stanie przynieść pozytywny efekt, a więc wywrzeć jakikolwiek wpływ na postępowanie państw i ich obywateli w przyszłości. Za znacznie bardziej doniosłe praktycznie należy więc uznać działania podjęte na gruncie międzynarodowej odpowiedzialności karnej jednostek.

Już 1 lipca 2012 r. prokurator MTK Fatou Bensouda wystosowała publiczne oświadczenie, w którym podkreślała, że celowe niszczenie świątyń położonych w Timbuktu stanowi na gruncie Statutu Rzymskiego zbrodnię wojenną ${ }^{22}$. Wkrótce okoliczności sprawy zbadano w trakcie przeprowadzonego na wniosek malijskiego rządu postępowania dochodzeniowego ${ }^{23}$. Na podstawie zgromadzonych podczas czynności śledczych oraz postępowania przygotowawczego materiałów procesowych wydano nakaz aresztowania Ahmada Al Faqi Al Mahdi. Zgodnie z twierdzeniem oskarżenia stał on na czele

18 Timbuktu-manuskryptyocalaty, http://www.polityka.pl/tygodnikpolityka/swiat/1535299,1,timbuktu--manuskrypty-ocalaly.read [dostęp: 22.02.2016].

19 ECOWAS (ang. Economic Community of West African States) - regionalna organizacja zrzeszająca 15 państw Afryki Zachodniej, utworzona 28 maja 1975 r. mocą traktatu z Lagos. Jej głównym celem jest promowanie integracji ekonomicznej.

$20 \mathrm{~W}$ dyskursie publicznym do dziś spotkać można opinie, że nie godzi się skupiać uwagi na bezpieczeństwie dóbr kultury, gdy w wyniku konfliktu zagrożone jest dobro wyższe- życie ludzkie.

21 Rezolucja 2056 (2012) z dnia 5 lipca 2012 r., dokument nr S/RES/2056, 2012. Teksty wszystkich rezolucji: http://www.un.org/en/sc/documents/resolutions/ [dostęp: 22.02.2016].

22 Republika Mali podpisała Statut Rzymski 17 lipca 1998 r., zaś ratyfikacji dokonała 16 sierpnia 2000 r. Będąc stroną Statutu, uznała tym samym jurysdykcję Trybunału w odniesieniu do wskazanych w art. 5 zbrodni. Na gruncie art. 12 Trybunał jest właściwy do sądzenia osób fizycznych, które są obywatelami państwa-strony traktatu lub popełniły zbrodnię na terenie takiego państwa. Tekst Rzymskiego Statutu Międzynarodowego Trybunału Karnego: Dz.U. 2003 nr 78 poz. 708.

23 Situation in Mali. Article 53(1) Report, 16 January 2013, https:/www.icc-cpi.int/en_menus/icc/ situations\%20and\%20cases/situations/icc0112/Documents/SASMaliArticle53_1PublicReport ENG16Jan2013.pdf [dostęp: 25.02.2016]. 
ugrupowania Ansar ad-Din, odpowiedzialnego za okupację Timbuktu oraz narzucanie ideologii szariatu jego mieszkańcom. Jako przywódca wyłonionej w ramach ruchu policji religijnej Hisbah nie tylko kierował niszczycielską działalnością, ale także czynnie uczestniczył w operacji destrukcji historycznych i religijnych budowli. Dlatego też wszystkie sformułowane wobec niego zarzuty skupiają się właśnie wokół zniszczeń dóbr kultury $^{24}$. Posiedzenie potwierdzające zarzuty oskarżenia odbyło się 1 marca 2016 r. Od tej daty Izba Przygotowawcza ma 60 dni na podjęcie stosownej decyzji ${ }^{25}$. W przypadku zatwierdzenia zarzutów sprawa zostanie przekazana, w trybie art. 61 ust. 11 Statutu, Izbie Orzekającej jako organowi właściwemu do jej prowadzenia. W mowie otwierającej posiedzenie zatwierdzające zarzuty Fatou Bensouda zwróciła uwagę nie tylko na historyczny i artystyczny wymiar zniszczonych dóbr kultury. Nie bez racji podkreślała, że mamy do czynienia nie tylko z fizyczną eliminacją świątyń, ale również z atakiem na tożsamość ludności, która je czciła. Po raz kolejny destrukcja kulturowego dziedzictwa uderzyła w godność i korzenie dzierżącej je grupy społecznej.

Bez wątpienia omawiana sprawa stanowi przełom w ochronie dóbr kultury rozpatrywanej z punktu widzenia penalizacji czynów przestępczych przeciwko nim skierowanym. Do tej pory problematyka ochrony dziedzictwa kulturowego pojawiała się w judykaturze sądów międzynarodowych w marginalnym wymiarze. W przypadku zaś obecnie rozpatrywanej sprawy zarzut naruszenia art. 8 ust. 2 lit. e pkt iv Statutu MTK znajduje się w centrum aktu oskarżenia. Taki rozkład akcentów pozwala przypuszczać, że planowany proces będzie stanowić krok milowy na drodze do skuteczniejszej ochrony kulturowego dziedzictwa w przyszłości.

$24 \mathrm{Na}$ gruncie art. 8 Statutu MTK: „1. Trybunał posiada jurysdykcję w odniesieniu do zbrodni wojennych, w szczególności popełnionych w ramach realizacji planu lub polityki albo kiedy zbrodnie te są popełniane na szeroką skalę. 2. Dla celów niniejszego statutu „zbrodnie wojenne” oznaczają: [...] (e) inne poważne naruszenia praw i zwyczajów w obrębie ustalonych ram prawa międzynarodowego mających zastosowanie do konfliktów zbrojnych, które nie mają charakteru międzynarodowego, mianowicie: [...] (iv) zamierzone kierowanie ataków na budynki przeznaczone na cele religijne, edukacyjne, artystyczne, naukowe lub charytatywne, pomniki historyczne, szpitale oraz miejsca, gdzie gromadzeni są ranni i chorzy, pod warunkiem że nie są one celami wojskowymi”. Al Mahdiemu zarzuca się popełnienie zbrodni wojennych polegających na celowym kierowaniu ataków przeciwko następującym budowlom: mauzoleum Sidi Mahmoud Ben Omar Mohamed Aquit, mauzoelum Sheikh Mohamed Mahmoud Al Arawani, mauzoleum Sheikh Sidi Mokhtar Ben Sidi Muhammad Ben Sheikh Alkabir, mauzoleum Alpha Moya, mauzoleum Sheikh Sidi Ahmed Ben Amar Arragadi, mauzoleum Sheikh Muhammad El Micky, mauzoleum Cheick Abdoul Kassim Attouaty, mauzoleum Ahamed Fulane, mauzoleum Bahaber Babadié oraz meczetowi Sidi Yahia.

$25 \mathrm{Na}$ mocy art. 61 ust. 7 Statutu MTK Izba Przygotowawcza na podstawie wyników posiedzenia może: a) zatwierdzić zarzuty oskarżenia, jeśli stwierdzi istnienie wystarczających dowodów dla przyjęcia uzasadnionego podejrzenia sprawstwa, b) odrzucić zarzuty oskarżenia, wobec których stwierdzi brak wystarczających dowodów, c) odroczyć posiedzenie i zobowiązać prokuratora do dostarczenia dalszych dowodów lub dalszego prowadzenia postępowania przygotowawczego, bądź zmiany zarzutów. 


\section{Zbrodnie Państwa Islamskiego przed MTK}

Poczynając od marca 2015 r., świat nieustannie obiegają drastyczne obrazy destrukcji kulturowego dziedzictwa w Syrii oraz Iraku. Pole rażenia niszczycielskiej działalności Państwa Islamskiego jest ogromne - ISIS sieje terror na bardzo rozległych już terytoriach. Okupowany obszar, stanowiący niegdyś kolebkę wielkich cywilizacji, do niedawna obfitował w liczne elementy kultury materialnej. Dziś, w wyniku prowadzonych czystek kulturowych, symbole ówczesnej potęgi i bogactwa świata arabskiego znikają bezpowrotnie z powierzchni ziemi. Eksterminacji mniejszości etnicznych i religijnych towarzyszy bowiem eliminacja wszelkich przejawów ich bytności na okupowanych obszarach. Masowa zagłada antycznego dziedzictwa kulturowego jest również motywowana względami religijnymi - wszelkie zabytki pochodzące z okresu przed ustanowieniem islamu ISIS uznaje za świętokradcze i promujące „bałwochwalstwo”. Według niektórych doniesień rzeczywistość jest zgoła inna - cenniejsze zabytki są sprzedawane, a osiągane zyski stanowią jedno z głównych źródeł finansowania terrorystycznej działalności. Z oczywistych względów największe oburzenie opinii publicznej wywołują akty kierowane systematycznie przeciwko obiektom wpisanym na Listę Światowego Dziedzictwa UNESCO ${ }^{26}$. Państwa są bowiem świadome, ,że uszkodzenie lub unicestwienie jakiegokolwiek dobra należącego do dziedzictwa kulturalnego lub naturalnego stanowi nieodwracalne zubożenie dziedzictwa wszystkich narodów świata”27. Cała wspólnota międzynarodowa stoi więc w obliczu wyzwania, jakim jest zapobieżenie tej kulturalnej katastrofie.

Zainteresowanie społeczności międzynarodowej tą problematyką przejawia się szczególnie w przyjmowanych przez Radę Bezpieczeństwa rezolucjach. W jednej z nich - rezolucji $2249^{28}$ - czytamy:

\section{[...] agresywna ekstremistyczna ideologia tzw. „ISIS/Daisz”, jego ataki terrorystycz-} ne, jego budzące odrazę nieustanne, systematyczne i powszechne ataki przeciwko

26 Syria posiada aż sześć takich obiektów, które w 2013 r. zostały przepisane na Listę dziedzictwa światowego w niebezpieczeństwie (List of World Heritage in Danger). Są to kolejno: starożytne miasta Aleppo, Bosra oraz Damaszek, starożytne wioski północnej Syrii, ruiny Palmyry oraz zamek krzyżowców Krak des Chevaliers i twierdza Kalat Salah ad-Din. W Iraku na kulturowe dziedzictwo o wyjątkowej powszechnej wartości składają się natomiast cztery obiekty: starożytne miasta Hatra i Aszur, archeologiczne miasto Samarra oraz cytadela w Irbilu. Wszystkie obiekty, poza ostatnim, widnieją na Liście dziedzictwa światowego w niebezpieczeństwie. Oznacza to, że 9 na 10 obiektów Światowego Dziedzictwa Ludzkości w Iraku i Syrii jest zagrożonych działaniami dżihadystów. Ponadto 11 obiektów z Iraku oraz 12 z Syrii widnieje na tzw. listach informacyjnych (tentative lists). Jest to wykaz dóbr zasługujących zdaniem państw na wpisanie na Listę. Dane UNESCO: http://whc.unesco.org/en/list/ [dostęp: 25.02.2016].

27 Fragment preambuły Konwencji w sprawie ochrony światowego dziedzictwa kulturalnego i naturalnego z $1972 \mathrm{r}$.

28 Rezolucja 2249 (2015) z dnia 20 listopada 2015 r., dokument nr S/RES/2249 (2015). 
ludności cywilnej, naruszenia praw człowieka i międzynarodowego prawa humanitarnego, w tym te popełniane na tle religijnym lub etnicznym, oraz niszczenie dziedzictwa kulturowego i nielegalny handel dobrami kultury stanowią globalne i bezprecedensowe zagrożenie dla międzynarodowego pokoju i bezpieczeństwa.

W rezolucji $2199^{29}$ nie tylko potępiono destrukcję kulturowego dziedzictwa, ale również nakazano wszystkim państwom członkowskim podjęcie odpowiednich kroków mających na celu przeciwdziałanie nielegalnemu handlowi antykami i innymi dobrami kultury pochodzącymi z Syrii oraz Iraku. W tym samym duchu przyjęto kolejny dokument - rezolucja $2253^{30}$ podkreśla potrzebę rozwijania ścisłych relacji z sektorem prywatnym w celu ukrócenia procederu finansowania działalności terrorystycznej. Warto zaznaczyć, że choć wskazane rezolucje stanowią ważny głos w toczącej się debacie politycznej, to ich praktyczne znaczenie jest znikome. Wydaje się bowiem mało prawdopodobne, by podmioty naruszające nawet najbardziej podstawowe normy prawa międzynarodowego zechciały postępować zgodnie z wytycznymi wynikającymi z rezolucji Rady Bezpieczeństwa. Należy więc poszukiwać innych rozwiązań służących zahamowaniu kulturalnego kryzysu, tj. mających na celu zapobieżenie popełnianiu kolejnych zbrodni wojennych. Dotychczas starano się wykazać, że najskuteczniejsze wydaje się podjęcie działań w sferze międzynarodowej odpowiedzialności karnej. Należy przemyśleć, czy taki sam mechanizm można zastosować do zbrodni popełnianych przez Państwo Islamskie na terytorium Syrii oraz Iraku, skoro żadne z tych państw nie jest stroną Statutu Rzymskiego. Do tego problemu odnosiła się już prokurator Fatou Bensouda w oświadczeniu z 8 kwietnia 2015 r. ${ }^{31}$ Wskazuje w nim, że MTK nie posiada jurysdykcji terytorialnej wobec zbrodni popełnionych na terytorium państw niebędących stronami Statutu. Istnieje co prawda możliwość pociągnięcia do odpowiedzialności sprawców będących obywatelami państwa-strony Statutu, jednakże z informacji, jakimi dysponuje prokurator, wynika, że w skład dowództwa ISIS wchodzą głównie Syryjczycy i Irakijczycy. Brak więc na tym etapie podstaw jurysdykcyjnych pozwalających wszcząć postępowanie przygotowawcze. Warto jednak pamiętać, że na gruncie art. 12 ust. 3 Statutu Rzymskiego państwo niebędące jego stroną może uznać jurysdykcję Trybunału w drodze deklaracji złożonej Sekretarzowi. Wydaje się jednak mało prawdopodobne, by Syria czy Irak skorzystały z tej możliwości. Większe nadzieje pokładano w mechanizmie przewidzianym w art. 13 pkt b Statutu. Przepis ten przyznaje Radzie Bezpieczeństwa ONZ prerogatywę

29 Rezolucja 2199 (2015) z dnia 12 lutego 2015 r., dokument nr S/RES/2199 (2015).

30 Rezolucja 2253 (2015) z dnia 17 grudnia 2015 r., dokument nr S/RES/2253 (2015).

31 Statement of the Prosecutor of the International Criminal Court, Fatou Bensouda, on the alleged crimes committed by ISIS, https://www.icc-cpi.int/en_menus/icc/press\%20and\%20media/press \%20releases/Pages/otp-stat-08-04-2015-1.aspx [dostęp: 3.03.2016]. 
do inicjowania postępowania przed $\mathrm{MTK}^{32}$. Takie rozwiązanie powoduje rozszerzenie jurysdykcji Trybunału na zbrodnie popełnione na terytorium lub przez obywateli państw niebędących stronami Statutu ${ }^{33}$. Skorzystanie z tej kompetencji próbowano przeforsować na forum Rady Bezpieczeństwa już w maju 2014 r. Projekt rezolucji w sprawie przekazania sytuacji w Syrii do MTK $^{34}$ spotkał się jednak ze sprzeciwem dwóch stałych członków Rady - Chin oraz Rosji. Weto pogrzebało nadzieje na pociągnięcie sprawców zbrodni do odpowiedzialności przed Trybunałem.

\section{Kwalifikacja czynów przestępczych skierowanych przeciwko dziedzictwu kulturowemu}

W toku rozważań nad karnoprawnym zabezpieczeniem systemu ochrony dóbr kultury należy zastanowić się nad prawną kwalifikacją czynów skierowanych przeciwko dziedzictwu kulturowemu. Analiza judykatury międzynarodowych trybunałów pozwala zauważyć, że wymierzone w nie bezprawne działania stanowią niewątpliwie zbrodnię międzynarodową ${ }^{35}$. Trudniejsze może okazać się jasne określenie, z którą ze zbrodni mamy wówczas do czynienia. Patrząc wstecz, zauważamy, że norymberski Międzynarodowy Trybunał Wojskowy, podejmując próbę egzekwowania międzynarodowego prawa humanitarnego z zakresu ochrony dóbr kultury, postrzegał tego typu akty wyłącznie jako zbrodnie wojenne. Jednocześnie podkreślał, że wymierzone w ludność żydowską prześladowania, będące jednym z przejawów zbrodni przeciwko ludzkości, objawiały się w sposób szczególny w niszczeniu ich synagog. Winnym zbrodni przeciwko ludzkości

32 Przepis odzwierciedla tym samym kompetencje Rady przyznane jej w rozdziale VII Karty Narodów Zjednoczonych, służące utrzymaniu lub przywróceniu międzynarodowego pokoju i bezpieczeństwa. W preambule Statutu MTK czytamy, że „poważne zbrodnie zagrażają pokojowi, bezpieczeństwu i pomyślności świata”, stąd też współpraca Rady Bezpieczeństwa iMTK wydaje się uzasadniona. Takie zjednoczenie sił popiera sama prokurator Fatou Bensouda, według której „walka z bezkarnością najbardziej destabilizujących i najcięższych zbrodni nie jest prerogatywą jednej instytucji, ale zbiorową odpowiedzialnością, której beneficjentem jest ludzkość". Cf. F. Bensouda, Whither ICC-UNSC Relations in the $21^{\text {st }}$ Century? Challenges and Opportunities, http://www.international-criminal-justice-today.org/arguendo/article/whithericc-unsc-relations-in-the-21st-century-challenges-and-opportunities/ [dostęp: 29.02.2016].

33 Szerzej na temat udziału Rady Bezpieczeństwa w inicjowaniu postępowania przed MTK: B. Krzan, Kompetencje Rady Bezpieczeństwa ONZ w międzynarodowym sqdownictwie karnym, Toruń 2009, s. 133-162.

34 Projekt rezolucji 348 (2014) z dnia 22 maja 2014 r., dokument nr S/2014/348.

35 Katalog tych zbrodni, dziś już dobrze ukonstytuowany, został po raz pierwszy przedstawiony w Statucie MTW. Wyodrębniono i zdefiniowano w nim trzy kategorie przestępstw: zbrodnie przeciwko pokojowi, zbrodnie wojenne oraz zbrodnie przeciwko ludzkości. Wkrótce katalog ten rozszerzono o zbrodnię ludobójstwa, dzięki przyjęciu Konwencji w sprawie karania i zapobiegania zbrodni ludobójstwa (Dz.U.1952 nr 2 poz. 9). 
uznano chociażby Juliusa Streichera, odpowiedzialnego za prześladowania Żydów, m.in. za podpalenie synagogi w Norymberdze $\mathrm{e}^{36}$.

Do podobnych wniosków doszedł MTKJ w sprawie Prokurator v. Blaskić37. Trybunał uznał, że ataki serbskich sił na meczety położone w bośniackim mieście Ahmići wymierzone były w tożsamość ludności muzułmańskiej. Miejscowość ta nie miała bowiem żadnego znaczenia strategicznego, które usprawiedliwiałoby przeprowadzony atak. Posiadała natomiast wyjątkową wartość dla tamtejszych wyznawców islamu - uznawana była za święte miejsce i symbol muzułmańskiej kultury w Bośni i Hercegowinie. Na tej podstawie Trybunał wskazał, że niszczenie instytucji przeznaczonych na cele religijne może stanowić formę prześladowania ${ }^{38}$. Dostrzeżono więc negatywny wpływ, jaki może wywrzeć na społeczeństwo zniszczenie jego kulturowego dorobku. Uznanie takich czynów za formę prześladowania jest zrozumiałe, jeżeli weźmie się pod uwagę fakt, że są one niejednokrotnie wymierzone w kulturową tożsamość grup religijnych lub etnicznych ${ }^{39}$.

36 Trial of the Major War Criminals Before the International Military Tribunal, Nuremberg, 14 November 1945 - 1 October 1946, s. 302.

37 V. Prokurator v. Blaskić, sprawa nr IT-95-14-T, orzeczenie Izby Orzekającej z dnia 3 marca $2000 \mathrm{r}$.

38 Zgodnie $\mathrm{z}$ art. 5 lit. h Statutu MTKJ prześladowanie stanowi jeden z przejawów zbrodni przeciwko ludzkości. Na mocy tego przepisu „Międzynarodowy Trybunał ma prawo do sądzenia osób odpowiedzialnych za następujące zbrodnie, jeżeli zostały one popełnione przeciwko jakiejkolwiek ludności cywilnej podczas konfliktu zbrojnego, niezależnie od tego, czy konflikt miał charakter międzynarodowy czy wewnętrzny: [...] (h) prześladowanie z powodów politycznych, rasowych i religijnych". Statut MTKJ nie wspomina co prawda o prześladowaniach z powodów kulturowych, jednakże Trybunał powiązał religijny charakter instytucji z ich wartością kulturową. Co ciekawe, Statut MTK w art. 7 ust. 1 lit. h, dotyczącym zbrodni przeciwko ludzkości, wspomina o prześladowaniu z powodów kulturowych: „Dla celów niniejszego statutu „zbrodnia przeciwko ludzkości” oznacza którykolwiek z następujących czynów, popełniony w ramach rozległego lub systematycznego, świadomego ataku skierowanego przeciwko ludności cywilnej: [...](h) prześladowanie jakiejkowiek możliwej do zidentyfikowania grupy lub zbiorowości z powodów politycznych, rasowych, narodowych, etnicznych, kulturowych, religijnych, płci (gender) $\mathrm{w}$ rozumieniu ustępu 3 lub $\mathrm{z}$ innych powodów powszechnie uznanych za niedopuszczalne na podstawie prawa międzynarodowego, w związku z jakimkolwiek czynem, do którego odnosi się niniejszy ustęp, lub z jakąkolwiek zbrodnią objętą jurysdykcją Trybunału”. Cf. Y. Gottlieb, Criminalizing Destruction of Cultural Property: A Proposal for Defining New Crimes under the Rome Statute of the ICC, „Penn State International Law Review” 2004-2005, Vol. 23, s. 873-874.

39 Przykłady sytuacji, w których akty tylko pozornie wymierzone w materialne obiekty były faktycznie próbą pozbawienia społeczności jej kulturowej tożsamości można mnożyć. Należy przywołać w tym miejscu chociażby zniszczenie Starego Mostu w Mostarze (Bośnia i Hercegowina). Łączył on mieszkańców zamieszkałych na dwóch brzegach rzeki Naretv. Ludność skupiona wokół mostu zaczęła być identyfikowana poprzez odwołanie do miejsca osiedlenia w pobliżu zabytku. Wyrosła wokół mostu społeczność uważała się za jego opiekuna, a założone wkrótce miasto zawdzięczało jej nawet swoją nazwę - Mostari, czyli strażnicy mostu. W trakcie wojny bośniackiej wschodni brzeg rzeki zamieszkiwany był przez muzułmanów, zaś brzeg zachodni zajmowali bośniaccy Chorwaci. Destrukcja mostu była w rzeczywistości zniszczeniem kulturalnego symbolu pojednania chrześcijaństwa $\mathrm{z}$ islamem oraz Wschodu z Zachodem. Jego upa- 
Akty polegające na niszczeniu dóbr kultury są często stosowane jako narzędzie represji wobec mniejszości - stanowią wówczas element strategii dehumanizacyjnej, mającej na celu zniszczenie wspólnoty poprzez destrukcję jej historii ${ }^{40}$. Dziedzictwo kulturowe, stanowiące niezbędny element każdej społeczności, ucieleśnia historię i wyznawany system wartości, pełni funkcję integracyjną i identyfikacyjną. $Z$ tych względów ataki na dobra kultury mogą nie tylko przyczynić się do eskalacji konfliktu, ale także utrudnić czy wręcz uniemożliwić odbudowę społeczeństw po wojnie.

$\mathrm{Na}$ tle przytoczonych uwag warto wspomnieć, że zarówno w doktrynie, jak i na gruncie prawa międzynarodowego o charakterze soft law pojawiają się propozycje rozszerzenia kategorii zbrodni przeciwko ludzkości o „akty mające na celu umyślne niszczenie dziedzictwa ludzkości na dużą skalę" ${ }^{41}$. Niekiedy zgłaszane są nawet śmielsze propozycje utworzenia zupełnie odrębnej, piątej kategorii zbrodni międzynarodowej, a mianowicie zbrodni przeciwko dziedzictwu kulturowemu ${ }^{42}$. W prawnym i politycznym dyskursie obecny jest również postulat wyróżnienia „kulturobójstwa” (cultural genocide) w ramach szerszej kategorii zbrodni ludobójstwa. Taka myśl przyświecała zresztą samemu twórcy koncepcji ludobójstwa - Rafałowi Lemkinowi ${ }^{43}$. Za jego zasługą aspekt kulturowy uwzględniono przy formułowaniu prawnej definicji w pierwszej i drugiej wersji projektu Konwencji w sprawie zapobiegania i karania zbrodni ludobójstwa z 1948 r. ${ }^{44}$ Ostateczna wersja Konwencji nie wspomina co prawda o „kulturobójstwie”, ale pozostałości tej idei wciąż są obecne w międzynarodowym dyskursie. Terminem tym posługiwano się chociażby w kontekście kulturalnej katastrofy, do której doszło w latach 90. podczas

dek może stanowić symbol odejścia od pokojowej koegzystencji między narodami. V. K. Kawczyńska, Dezintegracja Jugostawii. Most w Mostarze - symbol dialogu i wojny kultur, Poznań 2014, s. 98-101.

40 R. O'Keefe, Protection of cultural property under international criminal law, „Melbourne Journal of International Law" 2010, vol. 11(2), s. 380-385.

41 „Parlament Europejski [...] wzywa UE do podjęcia niezbędnych kroków, by we współpracy z UNESCO i Międzynarodowym Trybunałem Karnym rozszerzyć kategorię prawa międzynarodowego dotyczącą zbrodni przeciwko ludzkości w taki sposób, aby uwzględnić też akty mające na celu umyślne niszczenie dziedzictwa ludzkości na dużą skalę”. Cf. rezolucja Parlamentu Europejskiego w sprawie niszczenia zabytków kultury przez Państwo Islamskie z dnia 30 kwietnia 2015 r., dokument nr 2015/2649(RSP), http://www.europarl.europa.eu/sides/get Doc.do?pubRef=-//EP//TEXT+MOTION+B8-2015-0391+0+DOC+XML+V0//PL[dostęp: 25.02.2016].

42 Cf. M. Lostal, Syria's world cultural heritage and individual criminal responsibility, „International Review of Law” 2015, Vol.3, http://dx.doi.org/10.5339/irl.2015.3 [dostęp: 26.02.2016].

43 Szerzej: D. Drużdż, Zbrodnia ludobójstwa w międzynarodowym prawie karnym, Warszawa 2010, s. 25-36.

44 Szerzej na temat ewolucji pojęcia „ludobójstwo”: H. Schreiber, Cultural genocide - ludobójstwo kulturowe - kulturobójstwo: niedokończony czy odrzucony projekt prawa międzynarodowego?, [w:] Kultura w stosunkach międzynarodowych, t. I, Zwrot kulturowy, red. H. Schreiber, G. Michałowska, Warszawa 2013, s. 252-274. 
konfliktu na Bałkanach. UNESCO używa natomiast pojęcia „czystka kulturowa” (cultural cleansing) w odniesieniu do aktów niszczenia syryjskiego dziedzictwa kulturowego, których „celem jest pozbycie się wszelkich przejawów obecności wspólnot religijnych i wyznaniowych innych niż te zgodne $z$ interpretacją islamu przez Państwo Islamskie oraz takich, które łączą ataki na fizyczne i materialne miejsca kultu, pamięci i nauki oraz na niematerialne formy wyrazu kulturowego, takie jak zwyczaj, tradycje i przekonania" ${ }^{45}$.

\section{Podsumowanie}

Problem przeciwdziałania aktom destrukcji kulturowego dorobku na dobre zagościł w dyskursie międzynarodowym. Dbałość o zachowanie dziedzictwa kulturowego w nienaruszonym stanie przejawia się dziś nie tylko w licznych regulacjach prawnych, ale także w istnieniu organizacji międzynarodowych stojących na straży tego dziedzictwa, w tym rzecz jasna najważniejszej - Organizacji Narodów Zjednoczonych ds. Wychowania, Nauki i Kultury (UNESCO). Oprócz tego na gruncie międzynarodowego prawa karnego podejmowane są wysiłki zmierzające do ukarania sprawców zbrodni wojennych wymierzonych w zasoby kulturowe. Rzecz jasna kara, następująca ze swej istoty post facto, nie „przywróci życia” skarbom kultury. Można mieć jedynie nadzieję, że będzie działać odstraszająco, pełniąc funkcję zarówno prewencji specjalnej, jak i ogólnej. Taki był zresztą zamysł twórców MTK. Powołano go przecież nie tylko w celu sądzenia popełnionych już zbrodni, ma on służyć również jako impuls do porzucenia zbrodniczych intencji przez kolejnych potencjalnych sprawców.

Sekretarz Generalny ONZ - Ban Ki-moon podczas pierwszej Konferencji Przeglądowej Statutu Rzymskiego, która odbyła się w 2010 r. w Kampali (Uganda), podkreślał, że stara era bezkarności dobiegła końca, a jej miejsce zajmuje dziś „era odpowiedzialności” (Age of Accountability) ${ }^{46}$. Miejmy nadzieję, że dzięki tej ewolucji wzrośnie bezpieczeństwo kulturowego dziedzictwa.

\section{Literatura}

Bensouda F., Whither ICC-UNSC Relations in the 21st Century? Challenges and Opportunities,http:/www.international-criminal-justice-today.org/arguendo/article/whithericc-unsc-relations-in-the-21st-century-challenges-and-opportunities/ [dostęp: 12.09. 2016].

45 Rezolucja Parlamentu Europejskiego w sprawie niszczenia zabytków kultury..., op. cit.

46 B. Ki-moon, Address to the Review Conference on the International Criminal Court: „An Age of Accountability", Kampala (Uganda), 31.05.2010, http://www.un.org/sg/STATEMENTS/index. asp?nid=4585 [dostęp: 7.03.2016]. The old era of impunity is over. In its place, slowly but surely, we are witnessing the birth of a new Age of Accountability. 
Bokova I., Culture in the Cross Hairs, „The New York Times”, 2.12.2012, http://www. nytimes.com/2012/12/03/opinion/global/cultural-sites-must-be-protected.html [dostęp: 12.09.2016].

Drużdż D., Zbrodnia ludobójstwa w międzynarodowym prawie karnym, Warszawa 2010. Gottlieb Y., Criminalizing Destruction of Cultural Property: A Proposal for Defining New Crimes under the Rome Statute of the ICC, „Penn State International Law Review” 2004-2005, Vol. 23.

Izydorczyk J., Wiliński P., Międzynarodowy Trybunat Karny. Powstanie, organizacja, jurysdykcja, akty prawne, Kraków 2004.

Kawczyńska K., Dezintegracja Jugostawii. Most w Mostarze - symbol dialogu i wojny kultur, Poznań 2014.

Ki-moon B., Address to the Review Conference on the International Criminal Court: "An Age of Accountability", Kampala (Uganda), 31 May 2010, http://www.un.org/sg/STATEMENTS/index.asp?nid=4585 [dostęp: 12.09.2016].

Krzan B., Kompetencje Rady Bezpieczeństwa ONZ w międzynarodowym sq̨downictwie karnym, Toruń 2009.

Lostal M., Syria's world cultural heritage and individual criminal responsibility, „International Review of Law" 2015, Vol. 3, http://dx.doi.org/10.5339/irl.2015.3 [dostęp: 12.09.2016].

O'Keefe R., Protection of cultural property under international criminal law, „Melbourne Journal of International Law" 2010, Vol.11(2).

Petrovic J., What next for endangered cultural treasures? The Timbuktu crisis and the responsibility to protect, „New Zealand Journal of Public and International Law” 2013, nr 11.

Ratkowić D., Chorwacja, skutki wojny, „Cenne, bezcenne/utracone” 1997, nr 2

Schreiber H., Cultural genocide - ludobójstwo kulturowe - kulturobójstwo: niedokończony czy odrzucony projekt prawa międzynarodowego?, [w:] Kultura w stosunkach międzynarodowych, t. I, Zwrot kulturowy, red. H. Schreiber, G. Michałowska, Warszawa 2013.

Schreiber H., Konwencja o ochronie dóbr kulturalnych w razie konfliktu zbrojnego wraz z Regulaminem wykonawczym do tej Konwencji oraz Protokót o ochronie dóbr kulturalnych w razie konfliktu zbrojnego podpisane w Hadze dnia 14 maja 1954 r., [w:] Konwencje UNESCO w dziedzinie kultury. Komentarz, red. K. Zalasińska, Warszawa 2014.

Situation in Mali. Article 53(1) Report, 16 January 2013, https://www.icc-cpi.int/en_menus/icc/situations\%20and\%20cases/situations/icc0112/Documents/SASMaliArticle53_1PublicReportENG16Jan2013.pdf [dostęp: 12.09.2016].

State of Conservation (SOC): Timbuktu (2013), http://whc.unesco.org/en/soc/1865 [dostęp: 12.09.2016].

Statement of the Prosecutor of the International Criminal Court, Fatou Bensouda, on the alleged crimes committed by ISIS, https://www.icc-cpi.int/en_menus/icc/press\%20and\%20 media/press\%20releases/Pages/otp-stat-08-04-2015-1.aspx [dostęp: 12.09.2016]. 
Timbuktu-manuskrypty ocalaty, http://www.polityka.pl/tygodnikpolityka/swiat/1535299, 1,timbuktu--manuskrypty-ocalaly.read [dostęp: 12.09.2016].

Tuaregs claim 'independence' from Mali, http://www.aljazeera.com/news/africa/2012/04/ 20124644412359539.html [dostęp: 12.09.2016].

Tymowski M., Dzieje Timbuktu, Wrocław - Warszawa - Kraków - Gdańsk 1979.

Vattel E., Prawo narodów, czyli zasady prawa naturalnego zastosowane do postępowania i spraw narodów i monarchów, t. 2, Warszawa 1958.

I Protokół dodatkowy do konwencji genewskich z 12 sierpnia 1949 r., dotyczący ochrony ofiar międzynarodowych konfliktów zbrojnych, Genewa, 8 czerwca 1977 r., Dz.U. 1992 nr 41 poz. 175, załącznik.

Drugi Protokół do Konwencji o ochronie dóbr kulturalnych w razie konfliktu zbrojnego, podpisanej w Hadze dnia 14 maja 1954 r., Haga, 26 marca 1999 r., Dz.U. 2012 poz. 248.

Karta Międzynarodowego Trybunału Wojskowego, Londyn, 8 sierpnia 1945 r., Dz.U. 1947 nr 63 poz. 367.

Konwencja dotycząca praw i zwyczajów wojny lądowej, Haga, 18 października 1907 r., Dz.U. 1927 nr 21 poz. 161.

Konwencja dotycząca środków zmierzających do zakazu i zapobiegania nielegalnemu przywozowi, wywozowi i przenoszeniu własności dóbr kultury, Paryż, 17 listopada 1970 r., Dz. U. 1974 nr 20 poz. 160.

Konwencja o ochronie dóbr kulturalnych w razie konfliktu zbrojnego, Haga, 14 maja 1954 r., Dz.U. 1957 nr 46 poz. 212.

Konwencja w sprawie karania i zapobiegania zbrodni ludobójstwa, uchwalona przez Zgromadzenie Ogólne Narodów Zjednoczonych, 9 grudnia 1948 r., Dz.U. 1952 nr 2 poz. 9.

Konwencja w sprawie ochrony światowego dziedzictwa kulturalnego i naturalnego, $\mathrm{Pa}-$ ryż, 16 listopada 1972 r., Dz.U. 1976 nr 32 poz. 190.

Projekt deklaracji międzynarodowej dotyczącej praw i zwyczajów wojny (Deklaracja brukselska), Bruksela, 27 sierpnia 1874 r., [w:] S. Nahlik, Międzynarodowa ochrona dóbr kulturalnych. Zbiór tekstów, Warszawa 1962.

Projekt rezolucji 348 (2014) z dnia 22 maja 2014 r., dokument nr S/2014/348.

Prokurator v. Blaskić, sprawa nr IT-95-14-T, orzeczenie Izby Orzekającej z dnia 3 marca $2000 \mathrm{r}$.

Prokurator v. Miodrag Jokić, sprawa nr IT-01-42/1-S, orzeczenie Izby Orzekającej $\mathrm{z}$ dnia 18 marca $2004 \mathrm{r}$.

Prokurator v. Pavle Strugar, sprawa nr IT-01-42-T, orzeczenie Izby Orzekającej z dnia 31 stycznia 2005 r.

Prokurator v. Pavle Strugar, sprawa nr IT-01-42-A, orzeczenie Izby Apelacyjnej z dnia 17 lipca 2008 r. 
Rezolucja 2056 (2012) z dnia 5 lipca 2012 r., dokument nr S/RES/2056 (2012).

Rezolucja 2199 (2015) z dnia 12 lutego 2015 r., dokument nr S/RES/2199 (2015).

Rezolucja 2249 (2015) z dnia 20 listopada 2015 r., dokument nr S/RES/2249 (2015).

Rezolucja 2253 (2015) z dnia 17 grudnia 2015 r., dokument nr S/RES/2253 (2015).

Rezolucja Parlamentu Europejskiego w sprawie niszczenia zabytków kultury przez Państwo Islamskie z dnia 30 kwietnia 2015 r., dokument nr 2015/2649(RSP).

Rzymski Statut Międzynarodowego Trybunału Karnego, Rzym, 17 lipca 1998 r., Dz.U. 2003 nr 78 poz. 708.

Statut Międzynarodowego Trybunału do Sądzenia Osób Odpowiedzialnych za Poważne Naruszenia Międzynarodowego Prawa Humanitarnego Popełnione na Terytorium byłej Jugosławii od 1991 r., Nowy Jork, 25 maja 1993 r., http://www.pck.org.pl/pliki/ mph/1993_Haga_-_Statut_MTKJ.pdf [dostęp: 12.09.2016].

Trial of the Major War Criminals Before the International Military Tribunal, Nuremberg, 14 November 1945 - 1 October 1946.

http://www.cro.pl/dubr2.php?param=1 [dostęp: 12.09.2016].

http://whc.unesco.org/en/list/ [dostęp: 12.09.2016].

http://whc.unesco.org/en/news/893/ [dostęp: 12.09.2016].

http://www.zod.hr/eng/novost.php?id=50 [dostęp: 12.09.2016].

\section{SUMMARY}

\section{The protection of cultural heritage in the International Criminal Courts}

The article aims to present the problem of the ineffectiveness of international legal instruments for the protection of cultural heritage. It presents examples of where such laws were violated and suggests that international criminal law can contribute to a better condition of cultural property. The author emphasizes that the International Criminal Court should play an important role in safeguarding such property from destruction in the future. In that context, the article presents inter allia the case of Ahmad Al Faqi Al Mahdi, which is claimed to be a milestone in the protection of cultural heritage.

Keywords: cultural heritage protection, destruction of cultural heritage, international criminal law, International Criminal Court, war crimes, crimes against humanity

Sylwia Stryjкowska, Adam Mickiewicz University Poznań, Faculty of Law and Administration, Al. Niepodległości 53, 61-714 Poznań, e-mail: sylwia.stryjkowska@amu. edu.pl. 